\title{
På tide å tenke nytt om psykiatriske diagnoser
}

\author{
Hvordan skal psykiatrisk sykdom kategoriseres? Den nye utgaven av Diagnostic and Statistical Manual \\ of mental disorders (DSM-5) har høstet sterk kritikk allerede før utgivelsen. En alternativ tilnærming \\ for å kategorisere psykiatrisk sykdom belyser viktige grunnlagsproblemer i psykiatrien.
}

\section{Anne Høye \\ anne.hoye@unn.no}

Det har vakt oppsikt at den amerikanske psykiateren Allen Frances, som ledet arbeidet med DSM-IV, har rettet kraftig kritikk mot DSM-5 (1). Han er bekymret over en innsnevring av normalitetsbegrepet, falske epidemier drevet av psykofarmakaindustrien, den amerikanske psykiaterforeningens avhengighet av salgsinntekter fra DSM-5 og de omfattende konsekvensene revisjonen vil ha for enkeltpasienter - ved at både behandlingsmessig og økonomisk søkelys dreies bort fra de alvorligst syke (2).

\section{Deskriptive kategorier}

DSM-III ble utgitt i 1980 (3) og representerte et vendepunkt i historien om klassifikasjon av psykiatriske diagnoser $(4,5)$. DSM-I og DSM-II var mer psykodynamisk orientert, og psykiske lidelser ble beskrevet som grader av tilpasningsforstyrrelser. DSM-III og den reviderte versjonen DSM-III-R innførte atskilte sykdomskategorier beskrevet ved operasjonelle kriterier, og man etterstrebet en såkalt teorinøytral beskrivelse med hovedvekt på empirisk validering for å underbygge kategoriene $(3,6)$. Interraterreliabilitet ble viktig, det vil si i hvilken grad to ulike observatører gir samme diagnose ved et gitt sett av symptomer hos en pasient.

Diagnosene, slik de ble beskrevet i DSM-III, hadde godt etablerte røtter i vestlig medisinsk historie, men det var klarere bånd til psykiaterne Emil Kraepelin (1856-1926) og Kurt Schneider (18871967) enn til Sigmund Freud (1856-1939) $(5,7,8)$. Definisjonen av mental sykdom ble dermed endret fra noe man gjorde eller kanskje var, som ledd i en utvikling, til noe man hadde. Kraepelins hovedkategorier dementia praecox og manisk-depressiv lidelse dannet grunnlaget for nye sykdomskategorier. Det som var et viktig moment hos Kraepelin ble imidlertid mindre tydelig - nemlig behovet for å forstå symptomer som manifestasjoner av underliggende nevrofysiologiske årsaker og som et samspill mellom nevrofysiologiske og psykologiske mekanismer $(7,8)$.

\section{En stein er en stein fordi den er stein} Både DSM- og ICD-manualene har vært nyttige ved at de etablerte et felles språk for forskning og klinisk praksis. Det ble eksplisitt uttrykt i DSM-III at det som utgangspunkt ikke lå noen antakelse bak om at kategoriene var validerte enheter (3). Likevel ble det forutsatt at det skulle skje en gradvis empirisk validering av de valgte sykdomskategoriene etter hvert som forskningen gikk fremover. Dette har langt på

\section{«Diagnosenes validitet har hele tiden vært pro- blematisk, altså hvor- vidt det som beskrives faktisk representerer
noe virkelig og «sant»»}

vei vært mislykket (9-13). Likevel er diagnosemanualenes kategorier i økende grad blitt brukt som om de faktisk representerer tilstander der man har kunnskap om årsaken. Dette er kanskje ikke så merkelig «The tendency has always been strong to believe that whatever received a name must be an entity or being, having an independent existence of its own,» sa den britiske filosofen John Stuart Mill (1806-73).

Den amerikanske psykiateren Steven Hyman beskriver dette som «the problem of reification» (9). Det vil si at diagnosene i økende grad behandles som om de er konkrete, naturlige enheter, selv om de i utgangspunktet har vært rene konstruksjoner. Diagnosenes validitet har hele tiden vært problematisk, altså hvorvidt det som beskrives faktisk representerer noe virkelig og «sant», noe som er vitenskapelig begrunnet (14). Dette problemet er blitt mer påtren- gende etter hvert som man ut fra avstemning har inkludert stadig flere diagnoser.

De siste årene har gitt oss mer kunnskap om genetikk, nevrofysiologi, nevropsykologiske mekanismer og språkutvikling. Det er en tiltakende frustrasjon over at denne kunnskapen i liten grad manifesterer seg i ny viten om etiologi, sykdomsforløp og behandling, og Hyman og andre (9-13) mener at de eksisterende diagnosekategoriene hindrer en mer omfattende forståelse. For å si det på en annen måte: Psykiatrisk forskning tar utgangspunkt i sykdomskategorier basert på klinisk manifestasjon av symptomer og tegn. Dette gjør at man leter etter én-til-én-forklaringer, selv om det blir mer og mer åpenbart at slike ikke finnes (11). Man står i fare for å få en sirkelargumentasjon: En stein er en stein fordi den er en stein.

Svakhetene ved slik forskning vises ved at man går seg vill i beskrivelser av omfattende komorbiditet, man får problemer med å avgrense én tilstand opp mot en annen og med å definere trekk ved bestemte diagnoser $(9,11)$. Hvis man for eksempel ønsker å undersøke mulige årsaker til tvangslidelse og tar utgangspunkt i en gruppe pasienter med denne diagnosen, vil felles årsaksfaktorer kunne begrunnes ut fra at pasientene tilhører samme diagnosegruppe. Avvikende funn kan tilskrives komorbiditet - har du en tvangslidelse, er risikoen for at du i løpet av livet også tilfredsstiller kriteriene for alvorlig depresjon $70 \%$, for bipolar lidelse er den $10 \%$. I tillegg har du økt risiko for posttraumatisk stresslidelse og andre angstlidelser (15). Hvis man i stedet kunne identifisere felles faktorer, for eksempel følelsesmessig respons på tap av kontroll, vil det gi en mer åpen tilnærming på tvers av eksisterende kategorier.

\section{Paradigmeskifte?}

Med bakgrunn i denne erkjennelsen er det i USA de siste par årene utviklet en helt ny tilnærming til konseptualisering av mentale lidelser, kalt The Research Domain Criteria (RDoC), som har fått mye mindre oppmerksomhet enn lanseringen av DSM-5. RDoCmatrisen er utviklet av The National Insti- 


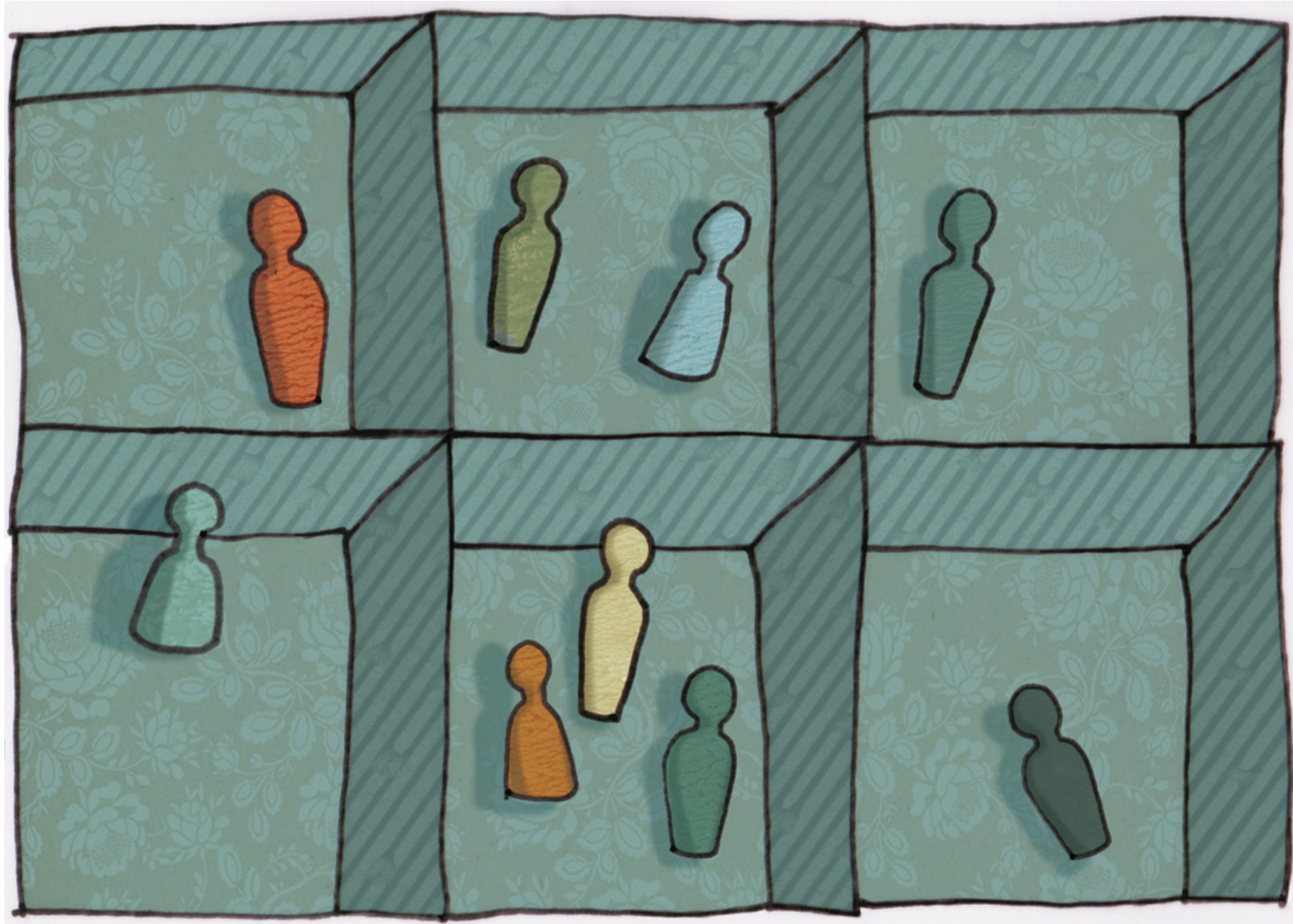

Illustrasjon @ Stein Løken

tute of Mental Health (NIMH) og representerer et radikalt brudd med eksisterende forskningskategorier innenfor psykiatrien. I den grad noe kan kalles begynnelsen på et paradigmeskifte, må det være dette.

Hovedintensjonen bak RDoC er å utvikle nye, valide kategorier som ivaretar faktisk kunnskap om ulike dimensjoner ved mentale lidelser: symptomer og atferd, de nevrobiologiske mekanismene som iverksetter dem og de genetiske og epigenetiske faktorene som ligger bak. Ambisjonene er store, men arbeidet er helt i startfasen og bærer mer preg av tenketank enn av system. Det er nedsatt arbeidsgrupper fra mange fagområder, og nødvendigheten av en transparent og åpen prosess understrekes (10-12).

I RDoCs strategidokument fra juni 2011 beskrives tre hovedprinsipper (16). For det første vektlegges dimensjoner, ikke kategorier. Dimensjonene representerer ulikt nivå av for eksempel biologisk aktivitet eller egenrapporterte symptomer. For det andre forholder man seg ikke til eksisterende diagnoser - utgangspunktet skal være sam- menhenger mellom nevrobiologi og atferd, som deretter kan knyttes til kliniske fenomener. For det tredje er det gjort forsøk på å definere en rekke ulike «constructs» (konstruksjoner), for eksempel frykt, tap, persepsjon og kognisjon. Disse kan belyses gjennom ulike former for analytisk tilnærming, for eksempel innen genetikk, fysiologi, atferd eller egenrapportering.

Det er en uttalt målsetting at forskere kan benytte uavhengige mål fra ulike analyseområder. Konstruksjonene som er valgt, er ikke fastsatt. De er nyttige ideer, som i beste fall kan være utgangspunkt for en kontinuerlig prosess mot mer valide konstruksjoner.

\section{Mange diagnoser, felles grunnlag}

Tenkningen kan illustreres ved at det $\mathrm{i}$ over hundre år har eksistert et klart skille mellom schizofreni og bipolar lidelse, støttet av forskning som har vist at både sykdomsforløp og respons på medisiner er forskjellig. Nyere genetiske studier viser imidlertid at det er høy grad av genetisk overlapping mellom disse tilstandene $(17,18)$.
I en stor internasjonal studie publisert i The Lancet i februar 2013 fant man at diagnosegrupper som schizofreni, bipolar lidelse, autisme, depresjon og AD/HD kan ha felles genetiske risikofaktorer (19). I en annen studie ble språkforstyrrelser hos pasienter med schizofrenispektrumlidelser og ulike stemningslidelser undersøkt (20). Man fant her at stabile språkforstyrrelser var sterkere assosiert med alvorlighetsgrad av psykose, sosialt funksjonsnivå og symptomer på tilbaketrekning enn med diagnosegruppe.

\section{Lang vei frem}

RDoC er ment å være starten på et nytt strategisk rammeverk for forskning og skal ikke erstatte eksisterende diagnosemanualer. Det vil likevel bli interessant å se i hvilken grad prinsippene som belyses vil innvirke på prosessene innenfor DSM- og ICD-systemene DSM-5 med de åpenbare svakhetene som er påpekt av blant andre Allen Frances, og ICD-11 som vil erstatte ICD-10 i løpet av få år. I tillegg til å være viktige kliniske verktøy 
er eksisterende diagnostiske kategorier grundig sementert både i farmasøytisk industri, i forsikringsbransjen og i helsetjenestens finansieringsordninger. Det er urealistisk å anta at en skute med såpass tung last vil skifte kurs med det første.

I arbeidet med RDoC har man så langt lagt mer vekt på basalforskningen enn på klinisk forskning. Dette har ført til en viss bekymring for at finansiering av kliniske prosjekter nedprioriteres (21). Funn fra klinisk, epidemiologisk og psykologisk forsk-

\section{«Hovedintensjonen bak RDoC er å utvikle} nye, valide kategorier som ivaretar faktisk kunnskap om ulike dimensjoner ved mentale lidelser»

ning vil likevel få stor betydning når det gjelder utforming av valide «constructs» innenfor den foreslåtte modellen og kan gi ny giv til relevante kliniske forskningsspørsmål. I Norge har vi et godt utgangspunkt for å se nærmere på prinsippene bak $\mathrm{RDoC}$ for planlegging av psykiatrisk forskning. Vi har gode miljøer innenfor klinisk og epidemiologisk forskning samt basalforskning, vi har helseregistre som kan benyttes for å belyse både arv, biologiske faktorer og miljøfaktorer og vi har offentlige finansieringsordninger som burde kunne gjøre oss mer uavhengige av eksisterende diagnosesystemer enn for eksempel USA.

Den umiddelbare kliniske nytten av strategien er ikke så lett å se. Det er likevel å håpe at forskning som integrerer genetikk, nevrobiologi og psykologi på sikt vil føre til en mer valid klassifikasjon, noe som kan få stor betydning for både klinisk evaluering og behandling.
Uavhengig av hvilken retning initiativet rundt $\mathrm{RDoC}$ tar, er det interessant og oppløftende at man setter i gang et prosjekt der man tar tak i viktige grunnlagsproblemer i psykiatrien. Kanskje vil «schizofreni» også være «schizofreni» om 50 år, men forhåpentligvis kan vi slippe å se normal sorgreaksjon eller raserianfall hos barn definert som patologisk (DSM-5). For å sitere Steven Hyman (9): «Epidemiology, genetics, psychology and neuroscience has not been kind to the DSM-IV categories, nor have these categories been kind to science. The DSM-III-R was a brilliant advance that prioritized interrater reliability, now it is time to move on.»

\section{Anne Høye (f. 1961)}

er lege og spesialist i psykiatri, med doktorgrad på schizofreni og kjønnsforskjeller. Hun er leder for Registerenheten ved Senter for klinisk dokumentasjon og evaluering (SKDE) i Helse Nord, med $50 \%$ postdoktorstipend ved Universitetssykehuset Nord-Norge fra januar 2013. For tiden er hun i ett års forskningspermisjon ved Harvard School of Public Health i Boston. Forfatter har fylt ut ICMJE-skjemaet og oppgir ingen interessekonflikter.

\section{Litteratur}

1. Madsen OJ. Mens vi venter på DSM-V. Tidsskrif for norsk psykologforening 2013; 50: 42-3.

2. Frances A. DSM-5 is a guide, not a bible: simply ignore its 10 worst changes. Huffington Post 12.3.2012. www.huffingtonpost.com/allen-frances/ dsm-5_b_2227626.html (6.5.2013).

3. Diagnostic and Statistical Manual of mental disorders. 3. utg. Washington D.C.: American Psychiatric Association, 1980.

4. Berrios GE. The history of mental symptoms: descriptive psychopathology since the nineteenth century. Cambridge: Cambridge University Press, 1996.

5. Clegg JW. Teaching about mental health and illness through the history of the DSM. Hist Psychol 2012; 15: 364-70.

6. Robins E, Guze SB. Establishment of diagnostic validity in psychiatric illness: its application to schizophrenia. Am J Psychiatry 1970; 126: 983-7.

7. Palm U, Möller HJ. Reception of Kraepelin's ideas 1900-1960. Psychiatry Clin Neurosci 2011; 65 $318-25$

8. Decker HS. How Kraepelinian was Kraepelin? How Kraepelinian are the neo-Kraepelinians?-from Emil Kraepelin to DSM-III. Hist Psychiatry 2007; 18: $337-60$
9. Hyman SE. The diagnosis of mental disorders: the problem of reification. Annu Rev Clin Psychol 2010: 6: 155-79.

10. Morris SE, Cuthbert BN. Research Domain Criteria: cognitive systems, neural circuits, and dimensions of behavior. Dialogues Clin Neurosci 2012; 14: 29-37.

11. Sanislow CA, Pine DS, Quinn KJ et al. Developing constructs for psychopathology research: research domain criteria. J Abnorm Psychol 2010 119: $631-9$

12. Insel $T$, Cuthbert $B$, Garvey M et al. Research domain criteria (RDoC): toward a new classification framework for research on mental disorders. Am J Psychiatry 2010; 167: 748-51.

13. Ghaemi SN, McHugh PR. The concepts of psychiatry: a pluralistic approach to the mind and mental illness. Baltimore, MD: The Johns Hopkins University Press, 2003.

14. Kendell R, Jablensky A. Distinguishing between the validity and utility of psychiatric diagnoses. Am J Psychiatry 2003; 160: 4-12.

15. Murphy DL, Moya PR, Fox MA et al. Anxiety and affective disorder comorbidity related to serotonin and other neurotransmitter systems: obsessivecompulsive disorder as an example of overlapping clinical and genetic heterogeneity. Philos Trans R Soc Lond B Biol Sci 2013; 368: 20120435.

16. Research Domain Criteria - RDoC. www.nimh.nih.gov/research-funding/nimhresearch-domain-criteria-rdoc.shtml (6.5.2013).

17. Stefansson H, Ophoff RA, Steinberg S et al. Common variants conferring risk of schizophrenia. Nature 2009; 460: 744-7.

18. Demjaha A MacCabe JH, Murray RM. How genes and environmental factors determine the different neurodevelopmental trajectories of schizophrenia and bipolar disorder. Schizophr Bull 2012; 38 209-14.

19. Smoller JW, Craddock N, Kendler K et al. Identification of risk loci with shared effects on five major psychiatric disorders: a genome-wide analysis. Lancet 2013; 381: 1371-9.

20. Cohen AS, Najolia GM, Kim Y et al. On the boundaries of blunt affect/alogia across severe mental illness: implications for Research Domain Criteria. Schizophr Res 2012; 140: 41-5.

21. Gaemi N. Psychiatric diagnosis: where's the science? Comment. Medscape Psychiatry 19.5.2011. www.medscape.com/viewarticle/742619 (6.5.2013).

Mottatt 8.3. 2013, første revisjon innsendt 18.3. 2013, godkjent 6.5. 2013. Medisinsk redaktør Sigurd Høye.

늘 Engelsk oversettelse på www.tidsskriftet.no

Publisert først på nett 